\title{
4 \\ PELESTARIAN DAN EKSPANSI PASAR BATIK TULIS GEDHOG TUBAN DI ERA GLOBALISASI
}

\section{Karsam}

\begin{abstract}
Abstrak
B atik Gedhog is a traditional batik in the District Kerek, Tuban. Fabric of batik gedhog has a rough surface because it is made by hand. Motif batik gedhogtends to follow the flow pat-terned geometric rough cloth. Seeing by this condition, the authors worrybatik gedhog will be expire everlasting. On the basis of this research was conducted by reviewing about, first, how the traditional batik 'batik gedhog Tuban, both how business should be done to preserve the traditional batik Tuban, namely Batik Gedhog in this era of globalization and to address mar-ket expansion.

Objectives is to find strategies or ways for traditional batik preservation, namely batik gedhog Tuban in the present and the future, so batik gedhog Tuban can enterthe market competition in today's global economy era. To answer these problems the authors conducted research using qualitative descriptive methods. Several attempts to preserve batik gedhog Tuban is to improve the quality of fabric, pattern in the current era motif now, promo-tion, exhibition and increase brand emage. This study is expectedto be useful for the readers and the batik gedhog markers Tuban.
\end{abstract}

Keyword: Pelestarian, Batik Gedhog, Tradisional, Globalisasi

\section{PENDAHULUAN}

Tuba-tubi selasih dandi

Kain batik pakai berkemban

Cuba-cuba kasihkan kami

Kalau baik buatkan zaman

Apa guna berkain batik

Kalau tidak dengan sucinya

Apa guna berbini cantik

Kalau tidak dengan budinya

Kalau ke Temasik di tengahari

Siapkan pinggan berisi betik

Wajah nan ayu tampak berseri
Bila menyarung si kain batik

Dipetik dari: Mingguan Malaysia, 21hb. Ogos, 1988.

Ungkapan pantun-pantun di atas membuktikan bahwa batik merupakan seni tradisi yang bersifat turun-temurun, merupakan pusaka peninggalan nenek moyang yang harus dilestarikan dan dipertahankan sampai akhir zaman. Bagi masyarakat Indonesia sekarang ini, batik telah menjadi salah satu identitas budaya bangsa yang sangat bernilai. Di dunia internasional, batik Indonesia mula dikenal sebagai salah satu bentuk tekstil khas Indonesia.

Hal ini terjadi bukan han-ya karena batik telah diakui oleh Unesco tahun 2009, bahwa batik merupakan war-isan budaya dunia, namun sejak tahun 1955 batik merupakan kekayaan Indone-sia. Seperti yang dijelaskan oleh Anesia Aryunda Dofa dalam bukunya yang ber-judul 
"Batik Indonesia" (1996: 1), bahwa pada saat Sidang APEC (Asia Pacific Econ-omy Council) berlangsung di kota Bogor, Jawa Barat pada tahun 1995 yang lalu, ketika para ketua negara yang bergabung dari negara-negara di Asia-Pasifik itu berkumpul, nampak dengan bangga mere-ka mengenakan pakaian batik.

Fajar Ciptandi (2013) dalam blog. Stisitelkom.ac.id mengatakan bahwa batik merupakan warisan budaya yang tidak hanya bicara pemaknaan filisofis dan estetika semata, tetapi batik berperan dalam roda perekonomian sebagai salah satu komoditi yang sangat penting. Batik pada saat ini bukan hanya menjadi kekayaan budaya nusantara, melainkan telah men-jadi milik dunia. Dengan demikian batik menjadi potensi besar dalam persaingan pasar global.

Era globalisasi membawa pengaruh terhadap eksistensi batik Indonesia saat ini. Mulai dari perkembangan motif dengan pengaplikasian motif menggunakan komputer, penggunaan canting elektrik, perkembangan bahan meliputi kain dan pewarna menjadi salah satu efek perkembangan batik saat ini.

Pengaruh globalisasi juga dapat meningkatkan peluang batik sebagai ko-moditi eksport dan mampu menambah pendapatan ekonomi negara. Namun dibalik itu semua muncul sebuah pertan-yaan, apakah untuk mewujudkan hara-pan di atas performa batik Indonesia yang ada saat ini sudah cukup baik? Yang kedua bagaimana perkembangan batik tradisional ke depannya, seperti batik gedhog Tuban? Yang mana sampai hari ini batik gedhog Tuban mulai menenun kain, membatik dan mewarna masih dikerjakan dengan manual/tangan manusia.

Perkembangan zaman yang semakin pesat, ilmu pengetahuan dan teknologi yang semakin canggih seperti di Tiongkok segala bidang dilaksanakan dengan IT (In-formation Technology) dan komputer yang serba canggih berpengaruh pada perkembangan seni dan budaya.

Pada mulanya motif dikerjakan dengan tangan secara manual, saat ini dapat dik-erjakan dengan menggunakan komputer dengan cepat dan bermacam-macam motif untuk memenuhi keperluan pembeli. Pem-buatan kain dengan teknologi yang canggih mengalami persaingan di seluruh dunia penghasil kain batik, seperti Dubai, Laos, Indonesia, Malaysia, Vietnam dan sebagainya.

Di bidang otomotif saat ini dikemukaan oleh Andre Vinsent Wenas (2013) dalam repository.usu.ac.id bahwa di pasar global Tiongkok mencatatkan 51\% kenaikan penjualan. Hal ini menunjukkan bahwa Tiongkok menguasai pangsa pasar di Asia saat ini. Kalau kita rasakan mulai ta-hun 2012 barang-barang produk Tiongkok mulai sepeda motor, alat-alat elektrnok mulai menjamur di pasar Indonesia. Bukan hanya itu kain bercorak motif batik produk Tiongkok juga sudah mulai berdatan-gan ke pasar Indonesia.Kondisi ini bisa disebut sebagai globalisasi ekonomi.

Globalisasi ekonomi adalah suatu kondisi dimana perekonomian nasional dan lokal terintegrasi dalam satu perekonomian tunggal yang bersifat global (Purbaya Budi Santosa, 2004). Dengan kondisi seperti ini dikuatirkan akan mem-bawa efek buruk terhadap perkembangan batik Indonesia, khususnya batik tulis tradisional.

Munculnya alat-alat yang serba canggih sangat mempengaruhi pembuatan kain batik tulis. Selain pengaruh yang posi-tif ia berkemungkinan akan membawa pupusnya seni tradisi, sehingga masyara-kat yang akan datang tidak mengenalinya lagi. Apabila dilihat dari segi ekonomi kain batik mempunyai kecenderungan harga yang mahal jika dibandingkan dengan kain yang lain-lain, masalah demikian dikhuatirkan dapat menimbulkan ku-rangnya minat masyarakat terhadap seni batik. Apalagi kain batik yang berkualitas tinggi hanya mampu digunakan oleh masyarakat golongan menengah ke atas.

Berdasarkan penjelasan di atas penelitian ini akan mengkaji tentang

1. Bagaimana proses batik tradisional "batik gedhog Tuban? 
2. Bagaimana usaha yang harus dilakukan untuk me-lestarikan batik tulis tradisional Tuban, yaitu Batik Gedhog di era globalisasi ini dan untuk menyikapi ekspansi pasarnya?

Tujuan yang ingin dicapai adalah menemukan strategi atau cara-cara peles-tarian batik tradional, yaitu batik gedhog Tuban di masa sekarang dan akan datang, sehingga batik gedhog Tuban dapat mengikuti persaingan pasar di era ekonomi global saat ini. Untuk mencapai tujuan dan untuk menjawab rumusan masalah tersebut di atas penulis melakukan riset dengan menggunakan metode diskriptif kualitatif. Data dikumpulkan melalui riset secara langsung di lapangan, tanya jawab ter-hadap para pembatik gedhog, dokumenta-si dan studi literatur. Artikel ini diharapkan dapat bermanfaat bagi para pembaca umumnya dan para pembatik gedhog di Kabupaten Tuban.

Berdasarkan buku Kabupaten Tuban Dalam Angka 2000 (2000: 1) Kabupaten Tuban terletak di antara 111,300 - 112,350 Bujur Timur dan 6,400 - 7,180 Lintang Selatan. Tuban terletak di pantai utara Jawa Timur, sekitar $100 \mathrm{~km}$, sebelah barat kota Surabaya. Tuban merupakan salah satu kota tua yang berada di sepanjang Pantai Utara Pulau Jawa. Pada masa kini sedang berkembang alat transportasinya jalur darat dan laut, terutama setelah didirikan perusahaan Semen di Kecamatan Kerek pada bulan Januari 1996 sebagai bagian dari perusahaan semen Kabupaten Gresik.

Kabupaten Tuban terdiri dari 19 kecamatan dan 328 desa. Dari 19 Kecama-taada 4 kecamatan penghasil batik, yaitu Kecamatan Palang, Semanding, Tuban dan Kerek. Dari 4 kecamatan tersebut, Kecamatan penghasil batik gedhog adalah Kecamatan Kerek. Di antara hasil budaya yang menonjol di Tuban adalah Tenun Gedhog dan Batik Tulis Gedhog tradisional.

Disebut tradisional karena pengerjaannya, bahan baku sampai barang jadi kerajinan dilakukan dengan cara tradisional, baik dalam pembuatan benang dari kapas, penenunannya maupun pewarnaannya. Tuban boleh menjadi daerah penghasil batik disebabkan oleh tanah Tuban yang kurang subur, yang sesuai ditanami kapas.

Dari buku Commodity Profile Batik. Traditional Tuban (2000: 6) dijelaskan bahwa perkebunan kapas di Kabupat-en Tuban meliputi enam Kecamatan, yaitu: Kecamatan Jenu, Kecamatan Merakurak, Kecamatan Tambakboyo, Kecamatan Bancar, Kecamatan Senori, dan Kecamatan Parengan dengan jumlah keluasan tanah 156,25 Ha. Jumlah produksi 47.157,5 ton per tahun.

KARSAM (2005) menjelaskan bahwa membatik adalah satu proses pekerjaan mengikut tahap-tahap tertentu. Jika dilihat dari sifat batikkannya dan berdasarkan tahap tersebut, para pembatik di Tuban terbagi dalam dua kelompok, yaitu pembatik tradisonal dan pembatik modern.

\section{Pembatik tradisional}

a. Pembatik

Pembatik ini bekerja dari proses menyiap-kan kain, melilin, melorod, mencuci dan menjemur sampai kain siap untuk dipakai.

b. Pedagang

Pedagang dalam hal ini tidak hanya bekerja untuk jual beli kain batik, ia juga bekerja mengumpulkan kain batik yang siap untuk diwedel dari para pembatik.

c. Tukang wedel

Tukang wedel adalah orang yang bekerja mewarna biru kain batik. Pekerjaan ini secara umum dilakukan oleh kaum laki-laki.

\section{Pembatik modern}

a. Pembatik

Pada batik modern seorang pembatik bekerja mulai dari menyiapkan kain sampai ke proses pelilinan saja.

b. Pewarna (Tukang mewarna) 
Setelah kain batik selesai dililin, langkah berikutnya adalah mewarna, melorod, mencuci dan menjemur. Tahapan ini dikerjakan oleh Tukang mewarna.

Tuban merupakan daerah pesisir, maka batik yang dihasilkan mempunyai ciri-ciri sebagai batik pesisir, seperti yang dijelaskan pada buku $B a$ tik and its Kind (1990: 6-9), bahwa batik Tuban mempunyai tata warna sebagai berikut:

\section{Batik putihan}

Batik putihan ini mempunyai latar belakang putih dengan corak motif biru tua atau hitam. Batik putihan oleh masyarakat Tuban dipakai untuk pakaian tolak bala, yaitu menolak/mencegah dari kena bahaya (setan).

Putihan berhubungan dengan istilah puasa di Jawa, yaitu mutih yang artinya puasa hanya makan nasi saja atau singkong saja tidak boleh pedas dan asin sebagai ritus mensucikan diri. Batik putihan dianggap sebagai lam-bang kemurnian dan kesucian.

\section{Batik bangrod}

Bangrod berasal dari dua perkataan Jawa, yaitu bang yang berarti abang atau merah, dan rod yang bererti dilorod atau dibersihkan lilinnya.

Batik bangrod adalah batik yang mempunyai dasar merah. Batik bangrod menurut kebiasaannya dipakai oleh para perempuan yang belum menikah. Hal ini dihubungkan dengan darah perempuan seperti menstruasi.

3. Batik pipitan

Kata pipitan berarti berdampingan. Batik pipitan adalah batik yang mempunyai da-sar remekan, yaitu dasar kain diblok dengan lilin kemudian sebelum diwarna lilinnya diremek/ dipecah-pecah atau diramas dengan tangan supaya lilinnya pecah-pecah supaya kemasukan warna, sehingga setelah diwarna ada kesan garis-garis.

Batik pipitan ini biasanya digunakan oleh wanita yang sudah menikah sebagai lambang hidup berdampingan dengan suami.

\section{Batik irengan}

Kata irengan berasal dari kata ireng yang berarti hitam. Batik irengan berarti batik yang bercorak atau berwarna hitam. Batik ini biasanya digunakan oleh orang tua. Selain itu batik irengan ini juga dipakai un-tuk penutup jenazah pada waktu disemadikan. Batik irengan ini dianggap sakral dan sebagai tolak bala demi kesela-matan arwah yang meninggal.

5. Batik lurik

Lurik berarti bercorak. Batik lurik merupa-kan ciri khas batik Tuban, sebab batik ini kalau dilihat dari bahannya merupakan hasil tenunan dari Kecamatan Kerek yang disebut sebagai batik gedhog. Batik lurik adalah hasil dari tenunan yang disebut dengan istilah lurik klontongan yaitu lurik dengan ragam hias kotak-kotak atau garis-garis hitam putih.

Caranya yaitu kain di-batik berbagai corak titik-titik dengan lilin. Setelah dicelup dengan warna merah mengkudu (morinda citri folia) dan lilinnya dibersihkan, maka akan diperoleh kain ba-tik lurik dengan corak titik-titik putih. Kain batik lurik biasanya dipakai sebagai paka-ian harian oleh kaum pria dan wanita.

Kain batik yang dihasilkan oleh para pembatik Tuban selain digunakan oleh masyarakat Tuban ia juga dijual ke daerah-daerah lain seperti ke Bali, Solo, Yog-yakarta dan Jakarta. Di samping itu kain batik juga dibeli oleh para pelancong da-lam negeri mahu pun luar negeri. Para pelancong ini datang ke daerah Tuban khususnya ingin berkunjung ke makam para wali/sonan yaitu SonAn Bonang (Wali Sembilan). Selain makam Sonan BonAng, di Kecamatan Palang juga ada makam seorang wali, yaitu Sonan Maulana Ibrahim Asmoro Qondi ayahnya Sonan Ampel (Wali Sembilan) dari Surabaya. Dengan adanya makam para wali ini, para peda-gang batik menjual kain batik di sekitar makam tersebut sebagai oleh-oleh para pelancong.

Batik merupakan salah satu sumber pendapatan negara dan mampu bertahan den- 
gan baik meskipun negara sedang menghadapi krisis ekonomi. Dalam menghadapi masa krisis tahun 1997, ternyata batik merupakan produk yang potensi mempunyai masa depan yang baik un-tuk dikembangkan. Dalam Internet, http:// www. satu-lelaki.com/tren/fesyen/0,19035,00. html dijelaskan, bahwa Menteri Perindustrian dan Perdagangan Rini Soewandi, menjelaskan berdasarkan statistik yang ada, nilai eksport batik pada tahun 2000 men-capai 322 juta dolar AS, atau meningkat $32.5 \%$ dibanding tahun sebelumnya 243 juta dolar AS. Selanjutnya beliau men-jelaskan bahwa batik akan tetap baik pada masa akan datang, karena terbukti tetap bertahan menjadi andalan eksport mes-kipun dihantam krisis pada tahun 1977.

Daftar Nilai Ekspor Batik Nasional 2004-2009

- Tahun 2004 US\$34,41 juta

- Tahun 2005 US\$12,46 juta

- Tahun 2006 US\$14,27 juta

- Tahun 2007 US\$20,89 juta

- Tahun 2008 USS 32,28 juta

- Triwulan I 2009 US\$10,86 juta

Sumber: Suara Pembaruan, 3 Oktober 2009.

Berdasarkan data hingga tahun 2009 ini dapat terlihat bahwa permintaan batik sebenarnya dari tahun 2004 sampai 2008 meningkat terus. Hanya di tahun 2009 mengalami penurunan.

Merujuk daftar di atas dan pesatnya industri negara lain, seperti Tiongkok, maka penulis berasumsi bahwa kondisi ini berdampak negatif terhadap perkem-bangan batik tradisional Tuban. Oleh karena itu perlu usaha untuk melestarikannya.

\section{PEMBAHASAN PROSES TENUN BATIK GEDHOG}

Batik Gedhog, yaitu batik yang menggunakan bahan kain dari tenun gedhog berwarna putih atau putih ke-coklatan yang dibuat oleh masyarakat Kecamatan Kerek sendiri.
Dinamakan batik gedhog karena saat proses menenun benang menjadi kain berbunyi 'dhog. .dhog'. Batik Gedhog Tuban (1992/1993: 9). Karsam (2005) menjelaskan bahwa proses "batik gedok" dilakukan dengan beberapa tahap, diantaranya:

1. Pengolahan Bahan Baku

a. Pembuatan Benang

- Menggiling Kapas

Sebelum dipintal untuk menjadi benang, maka kapas harus dibersihkan dari biji-bijinya. Kapas yang telah dipanen dari sawah, ladang atau dari halaman rumah perlu dikeringkan untuk beberapa saat sebelum digiling.

Proses penggilingan kapas dilakukan secara tradisional. Alat atau gilingan yang digunakan diperbuat dari kayu, dilengkapi dengan dua buah silinder sebagai penyepit. Dengan konstruksi ter-tentu salah satu dari silinder dapat diputar dengan tangan. Ketika silinder yang satu diputar dengan tangan, maka silinder yang satu lagi ikut berputar. Jarak antara silinder yang satu dengan silinder yang kedua diatur sedemikian rupa sehingga masih dapat dimasuki kapas, tetapi uku-ran sela-sela tersebut sangat sempit sehing-ga biji kapas tidak masuk ke dalamnya.

Kapas yang telah dikeringkan diuraikan untuk dibersihkan bijinya, pekerjaan ini disebut blibis. Kapas yang telah diuraikan tersebut, kemudian satu persatu dimasuk-kan ke dalam gilingan kapas agar biji-bijinya terlepas. Setelah digiling kapas menjadi padat, maka sebelum kapas dipintal kapas tersebut harus diuraikan lagi, pekerjaan ini disebut musoni.

- Musoni

Sebelum kapas dipintal menjadi benang, kapas tersebut harus diuraikan 
sampai bersih. Pekerjaan ini disebut musoni kare-na alat yang digunakan bernama pusona-tau usu. Alat ini berbentuk sangat seder-hana. Bentuknya seperti busur panah, dibuat dari bambu dan talinya dari nanas atau kulit kayu. Alat ini dilengkapi dengan alat lain yang disebut "jedhul" atau be-thuk. Bentuknya mirip alat pemukul drum tetapi ukurannya hanya sekitar $15 \mathrm{sm}$ atau $20 \mathrm{sm}$. Salah satu hujungnya dibuat sedi-kit besar sebagai kepala berbentuk bundar dibuat dari bahan kayu.

Musoni dilakukan dengan cara menggetar-getarkan usu dengan bethuk di atas tumpukan kapas yang telah disiapkan. Akibat getaran tali usu sedikit demi sedikit gumpalan-gumpalan kapas terhurai dan menyatu dengan gumpalan-gumpalan ka-pas lainnya. Kapas yang telah terurai se-lanjutnya digulung kira-kira sebesar geng-gaman tangan. Gulungan kapas ini bi-asanya disebut pusuhan. Setelah pusuhan itu siap berarti kapas tersebut siap untuk diantih atau dipintal.

- Mengantih atau Memintal

Mengantih adalah proses membuat be-nang setelah benang dipusoni. Proses ini menggunakan peralatan yang disebut jan-tra. Jantra diperbuat dari bahan kayu, bambu dan tali. Bagian penting alat ini adalah: roda, tali (klindhen) dan kisi. Alat untuk memintal bagian dari jantra ini disebut kisi. Alat ini diperbuat dari bahan kayu, panjangnya sekitar 20 sm dengan bentuk silinder. Bahagian pangkal ber-diameter atau garis tengah sekitar $75 \mathrm{~mm}$, bagian ujungnya dibentuk sedikit meruncing. Bagian tengah diberi cekungan melingkar tempat untuk mengikat tali. Dengan tali ini kisi dihubungkan ke roda jantra sihingga bila jantra diputar kisi pun ikut berputar.

Cara menggerakkan jantra, yai- tu: tangan kiri memegang kapas dan tangan kanan memutar roda jantra. Di bagian ujung kisi yang berputar dililitkan sedikit demi sedi-kit serabut kapas sehingga kapas tersebut tertarik secara perlahan menjadi benang. Benang yang dihasilkan biasanya disebut lawe. Nama ini untuk membedakan anta-ra benang yang dibuat dengan menggunakan mesin moden di pabrik dengan benang yang dihasilkan secara tradisional.

Untuk menghasilkan benang yang banyak juga diperlukan kisi yang banyak. Benang yang telah dihasilkan dari proses memintal atau mengantih ini masih belum lagi siap untuk ditenun. Sebelum dipersiapkan ke alat penenun benang tersebut harus betul-betul siap atau harus baik, sama ada untuk lungsen atau pun pakan. Pekerjaan ini disebut nglikasi.Benang yang telah dililit-kan menyilang pada likasan, selanjutnya dilepaskan dari likasan untuk dipersiap-kan, sehingga benar-benar siap untuk di-tenun.

Pekerjaan membuat benang meliputi tahap menggiling kapas, musoni dan mengantih diperlukan kerajinan/ ketekunan yang tinggi. Untuk memperoleh satu gulung be-nang lawe diperlukan waktu 4 sampai 6 hari dan seluruh proses pembuatannya dilakukan dengan tangan. Proses terakhir dari mengantih adalah memindahkan be-nang dari alat likasan. Pekerjaan ini sekali gus mengatur benang dalam bentuk gulungan dengan ukuran tertentu. Satu gulung atau satutukel berukuran sekitar 259,300 sm. Benang sepanjang ini dig-ulung dalam satu lingkaran dengan kelil-ing lingkaran sekitar $270 \mathrm{~cm}$. Untuk men-jaga agar gulungan benang tidak kusut atau ruwat, maka gulungan itu disusun dalam bentuk ikatan-ikatan benang. Tiap satu ikatan benang terdiri dari 5 helai be-nang yang disebut sekawan. Biasanya da-lam satu gulungan terdiri dari 118 ikat (kawan). 
Benang dalam bentuk gulungan ini yang akan dipersiapkan untuk di tenun.

b. Menenun

Setelah proses penyiapan benang selesai, maka tahap berikutnya adalah menenun. Benang yang akan ditenun/dianyam disiapkan menjadi dua bagi-an. Bagian benang yang disusun berbaris tegak lurus terhadap penenun atau benang yang membujur disebut lungsendan bagian benang yang sejajar terhadap penenun atau benang yang akan memben-tuk motif disebut pakan. Proses menenun di Kecamatan Kerek ini pada masa kini masih banyak ditemui di Desa Margorejo dan Desa Beji. Kedua-dua desa ini sejak dari zaman dulu dikenali sebagai desa penghasil tenun Kerek yang terkenal dengan nama "Tenun Gedhog”. Tahap menenun adalah mempersiapkan Benang Lungsen dan Benang Pakan, sebagai berikut :

\section{- Proses Nyekuli}

Benang lungsen diambil dari likasan dalam bentuk gulungan. Satu gulung bi-asanya disebut satu tukel. Sebelum dite-nun benang tersebut harus diolah lagi agar menjadi kuat dan sedikit keras atau kaku. Hal ini dilakukan dengan tujuan untuk mempermudahkan menyiapkan benang lawe menjadi benang lungsen dan pakan sekali gus mempermudahkan kerja menenun. Bahan yang digunakan untuk membuat benang menjadi kuat dan keras tersebut, yaitu menggunakan nasi dicam-pur sedikit air. Nasi dalam bahasa Jawa disebut sekul, oleh karena itu pekerjaan ini disebut nyekuli. Caranya: tiap gulung/tukel benang lawe yang akan disekuli dibentang atau diikat pada alat dari hujung ke hu-jung yang lain. Alat ini disebut tengker yang diperbuat dari dua potong bambu.

Bagian atas dari tenger ini dilengkapi dengan silinder dari kayu se- hingga mudah berputar. Benang yang telah dibentang dioles-olesi dengan nasi yang dicampur sedikit air dengan menggunakan kuas dari ijuk atau serabut kelapa sampai merata.

Ada juga pengrajin yang melakukan nyekuli ini dengan cara benang direbus campur nasi. Setelah itu benang disisir pakai serabut kelapa agar nasi yang menempel pada benang dapat diratakan dan bersih. Setelah proses nyekuli selesai kemudian benang tersebut dikeringkan dan setelah kering benang menjadi kuat, padat dan kaku.

- Menguraikan Benang

Untuk menghuraikan benang harus menggunakan alat yang disebut ingan. Alat ini dibuat dari bahan kayu berbentuk limas segi empat, dilengkapi dengan empat buah tangan yang bertumpu pada tiang atau poros ingan.

Alat ini dibentuk sedemikian rupa sehingga dapat berputar. Benang lawe yang masih dalam bentuk tukelan itu dipasang pada alat ini. Benang yang akan digunakan untuk kain tenun perlu diwarna, misalkan menggunakan naptol warna merah atau diwedel untuk menghasilkan warna biru kehitam-hitamanan. Tetapi untuk kain tenun yang akan dibatik tidak perlu diwarna, sehingga kekal berwarna putih.

Setelah tukelan/gulungan benang sudah dimasukkan ke dalam ingan, kemudian perlahan-lahan benang ditarik satu demi satu dan ditampung pada sebuah rinjing. Benang yang sedikit kaku dapat menghindari terjadinya keruwe-tan/keruwatan benang. Benang yang ter-tampung pada rinjing itulah yang akan digunakan untuk benang lungsen dan be-nang pakan.

Proses menyiapkan benang pakan dengan alat yang disebut kleting. 
Alat ini terbuat dari bambu seperti cucuk sate dengan ukuran panjang sekitar $20 \mathrm{~cm}$ dan garis tengahnya sekitar $1 \mathrm{~cm}$. Dengan jantra, benang digulung pada kleting dengan ukuran tertentu sehingga dapat dimasuk-kan ke dalam tropongyang diperbuat dari bahan bambu. Fungsi alat ini hampir sama dengan skoci pada mesin jahit.

- Manen

Setelah menyiapkan benang pakan langkah berikutnya, yaitu menyiapkan be-nang lungsen. Menyiapkan benang lungs-en ini lebih sulit dibanding dengan me-nyiapkan benang pakan. Proses awal mey-iapkan benang lungsen disebut manen ka-rena alat yang digunakan adalah panen.

Dengan alat panen ini benang lungsen dia-tur sama ada jumlahnya maupun uku-rannya. Jumlah benang atau deretan be-nang disesuaikan dengan ukuran panjang sisir dari alat tenun yang dimiliki. Sedangkan ukuran panjangnya disesuaikan dengan kegunaan kain tenun setelah selesai ditenun dan dibatik, misalnya untuk gendong.

Pada waktu pengrajin manen, tidak hanya sekadar mengatur deretan benang tetapi juga diatur agar benang tersebut dapat dipisah menjadi dua bagian, yaitu bagian atas dan bawah. Untuk mempermudah pekerjaan ini dibantu dengan alat yang disebut gun atau tali gun pada alat penenun. Dengan bantuan tali gun ini deretan benang bagian bawah dan atas mudah dipisahkan.

Pengaturan deretan lapisan benang dilakukan dengan mengangkat deretan benang berselang-seling. Lapisan dari deretan benang akan dipisahkan secara teratur oleh benang pa-kan. Dengan cara ini maka akan terjadi anyaman benang dan akhirnya akan ter-wujud kain yang dikehendaki. c. Proses Penenunan

Proses menenun diawali dari proses menyiapkan benang lungsen dan benang pakan. Benang lungsen diatur dengan tera-tur baik jarak maupun letaknya. Benang tersebut diatur sedemikian rupa dengan menggunakan sebuah alat dari bahan kayu yang disebut usek dan gun sehingga benang tersebut dapat dipilih menjadi dua lapisan, yaitu lapisan bawah dan atas. Lapisan ini untuk mempermudah mengatur benang pakan.

Semasa proses pengaturan benang posisi gun atau tali gun sangat menentukan. Posisi gun harus diusahakan tidak berubah oleh karena itu sebelum dilepas, tali gun diikatkan pada salah satu patok atau tiang panen harus dipindahkan ter-lebih dahulu pada sebuah alat tenun yang disebut gligen.

Untuk menghindari agar benang lungsen tidak ruwat atau berserakan, maka salah satu hujungnya harus diikat. Setelah itu pekerjaan selanjutnya adalah nyurupdanngelap.

- Nyurup

Nyurup adalah pekerjaan memasukkan benang lungsen pada sela-sela ruji dari sisir tenun. Seperti orang memasukkan benang pada jahit. Setiap sela-sela sisir tenun di-masuki dua helai benang. Selesai nyurup dilanjutkan dengan ngelap.

\section{- Ngelap}

Ngelap adalah pekerjaan mengatur be-nang lungsen pada bahagian dari alat tenun yang disebut gebeg atau papan. Sebelum dimasukkan ke alat tenun terlebih dahulu salah satu hujung benang lungsen diikat pada gebeg yang berfungsi untuk mengatur benang sesuai dengan jangkauan penenun.

Panjang benang lungsen sesuai dengan keperluan, kadang-kadang 
sepanjang 2 meter. Sedangkan jarak jangkauan tangan dan kaki penenun han-ya mencapai paling panjang 1 meter.

Ba-gian ujung benang lungsenyang lain sebe-lum digulung pada gebeg diikat pada se-buah alat tenun yang disebut apit, proses ini disebut murei. Alat tenun terdiri da-ripada: usek, gebeg, gun, apit, liro, dan lain-lain.

Semasa proses menenun berlangsung, yaitu menyusun benang lungsen dan benang pakan penenun dibantu sebuah alat yang disebut liro.

Alat ini diperbuat dari kayu berbentuk seperti pedang salah satu hujungnya runcing dan satu lagi hu-jungnya tumpul. Fungsi liro adalah per-tama, untuk merenggangkan sela-sela atau mengatur jarak benang lungsen, kedua, menghentak benang pakan setelah benang pakan dimasukkan ke dalam benang lungseng, sehingga anyaman benang men-jadi rata dan padat.

Dengan berkali-kali hentakan, maka benang pakan yang satu akan menjadi rapat dengan benang pakan yang lainnya sehingga jadilah sebuah kain tenun.

\section{PROSES BATIK GEDHOG}

Jika dilihat dari proses pewarnaannya, batik gedhog dibagi dua, yaitu batik gedhog soga pipit dan batik gedhog putihan atau irengan. Tahap proses batik gedhog adalah sebagai berikut:

\section{Persiapan dan Ngetel}

Apa yang dimaksudkan dengan tahap persiapan adalah proses penyiapan kain, iaitu kain yang akan dibatik harus dipersiapkan terlebih dahulu, misalnya kain tersebut untuk gendhong, sarung, dan lain-lain. Kain batik gedhog mempunyai perbedaan dengan kain batik lainnya.
Seperti yang telah dijelaskan di atas bahawa untuk menjadikan benang lawe menjadi kuat dan kaku sebelum ditenun benang lawe tersebut harus disekuli dengan menggunakan bubur nasi. Setelah kering bubur nasi tersebut menjadi keras dan mempermudah proses penenunan. Setelah menjadi kain tenun polos untuk dibatik, kain tersebut masih mengandungi bubur nasi yang sudah kering.

Bubur nasi yang melekat tersebut akan mengurangi lekat atau meresapnya bahan pewarna batik, oleh kerana itu sebelum dibatik kain terse-but harus dibersihkan dari lekatan bubur nasi dengan cara merendam kain tersebut selama lebih kurang dua hari. Proses inilah yang disebut dengan tahap ngetel.

Selain itu tahap ngetel bertujuan agar kain tenun yang telah bersih dari kandungan zat pengeras (bubur nasi) menjadi lebih lembut dan pori-pori benang terbuka lebih lebar sehingga memudahkan saat pelilinan dan pewarnaan.

\section{Membuat Motif}

Karena bentuk kainnya kasar dan bergar-is-garis, maka pada umumnya motif batik gedhog tradisional banyak menggunakan motif-motif geometris. Meskipun motif-motifnya berunsurkan tumbuhan tetapi motif tersebut digambar berbentuk "semetris" sehingga kelihatan berbentuk "geometris".

3. Ngengreng

Masyarakat pembatik di Kecamatan Kerek tidak menggunakan tahap mbaboni tetapi langsung ke tahap ngengreng. Tahap ngengreng atau disebut juga nglengreng adalah proses memberi lilin panas di atas kain mengikut pola atau motif yang telah dilakar.

4. Nerusi

Proses pelilinan ulang pada permukaan kain dibagian baliknya/belakang disebut nerusi.Tahap nerusi sangat diperlukan oleh para pembatik khususnya batik gedhog karena kain yang digunakan cenderung leb- 
ih kasar dan tebal jika dibandingkan dengan kain batik yang dari toko

5. Isen-isen

Untuk batik gedhog putihan atau irengan, setelah tahap nerusi dilanjutkan isen-isen, yaitu memberi isi pada motif utama dengan menggunakan lilin panas. Tetapi untuk batik gedhog soga pipit setelah ne-rusi langsung nembok. Isen-isen dilakukan setelah tahap nyoblosi.

6. Nembok

Tahap nembok adalah proses kelanjutan dari tahap ngengreng dan nerusi. Tahap ini sedikit berbeda dengan ngengreng. Ka-lau ngengreng menutup lilin pada bagian dasar kain sedangkan nembok bertujuan menutup bagian yang ada di dalam motif yang direncanakan untuk warna yang kedua atau pun ketiga dan seterusnya.

7. Nyoblosi

Apa yang dimaksudkan dengan nyoblosi adalah membuat lubang-lubang atau titik-titik kecil dengan menggunakan jarum atau duri jeruk dengan tujuan agar terkena warna biru nila (wedel). Nyoblosi ke-balikan dari nyeceki.

Kalau nyoblosi melubangi lilin pada kain agar terkena warna sedang nyeceki menutup kain dengan lilin agar tidak terkena warna.

Untuk batik gedhok putihan/irengan tahap nyoblosi dilakukan setelah tahap nembok, sedangkan untuk batik gedhok soga pipit tahap nyoblosi dilakukan setelah nyelup.

8. Nyelup

Nyelup adalah proses memasukkan kain batik ke dalam larutan warna (proses pewarnaan). Untuk batik gedhok putihan/irengan warna yang digunakan adalah warna biru atau gadung (wedel) se-bagai warna 1, sedangkan untuk batik gedhok soga pipit menggunakan warna me-rah (bahan kimia) sebagai warna 1. Pencelupan dilakukan berulang-ulang kali agar warna yang dihasilkan menjadi kuat.
9. Nggadungi

Nggadungi berasal dari kata gadung yang bererti biru. Nggadungi disebut juga se-bagai mbironi yang artinya membuat warna biru. Untuk batik gedhog putihan/irengansebelum tahap nggadungi adalah tahap nyelup warna dengan warna gadung sebagai warna pertama.

Setelah diwarna gadung kain akan dicelup kembali ke dalam warna coklat (soga) se-bagai warna ke dua. Supaya warna gadung tidak tertutup semua oleh warna coklat, maka bagian yang diinginkan men-jadi warna gadung harus ditutup dengan lilin panas, setelah itu baru celup ke dalam warna coklat (nyoga).

Jadi warna yang dihasilkan adalah warna putih (warna kain), warna biru, warna biru tua atau biru kehitam-hitaman yang diperolehi dari percampuran warna biru/gadung dengan warna coklat/soga. Oleh karena itu batik ini disebut batik gedhog putihanataubatik gedhog irengan.

Untuk batik gedhog soga pipit, setelah tahap nyelup warna merah, nyoblosi, is-enisen kemudian dicelup ke warna biru (wedel). Setelah diwedel kemudian nyoga. Warna yang dihasilkan adalah warna putih (kain), warna merah dan biru tua/biru kehitam-hitaman.

10. Nyoga

Seperti yang dijelaskan di atas setelah nggadungi adalah nyoga, yaitu mewarna kain dengan warna coklat (soga) yang ber-tujuan untuk mendapatkan warna biru tua atau biru kehitam-hitaman.

\section{Mematikan Warna (Fiksasi)}

Proses mematikan warna ini pada mulan-ya menggunakan endut atau lumpur dengan cara merendam ke dalam lumpur selama 24 jam. Pada saat ini untuk memat-ikan warna menggunakan tunjung.

12. Nyaren/nyarena

Setelah dimatikan warnanya kain dicuci 
dan dikeringkan kemudian disaren. Apa yang dimaksudkan dengan nyaren adalah proses pengulangan warna agar warna menjadi lebih kuat, biasanya dilakukan antara 5-7 kali.

13. Nglorod, Mencuci dan Mengering

Sama halnya dengan tahap membatik tulis yang lainnya, nglorod, mencuci dan men-gering, merupakan proses terakhir pem-batikan. Nglorod yaitu menghilangkan lilin dari kain batik kemudian setelah itu dicuci dan dikeringkan, maka selesailah proses membatik.

\section{PROSES PEWARNAAN BATIK GEDHOG}

Dari semua informan yang penulis temui, dan hasil dari penelitian langsung di lapangan serta data dari Permuseuman dalam buku Batik Gedhog Tuban (1992/1993: 30-40) proses pewarnaan dapat dibagi dua:

\section{Bahan Pewarna Alam}

Bahan pewarna alamyang digunakan ada dua jenis, yaitu soga dan nila (wedel). Soga adalah bahan pewarna batik yang menghasilkan warna coklat. Soga diper-buat dari bubukan kulit kayu, sedangkan nila adalah bahan pewarna batik yang menghasilkan warna biru, bahan ini di-perbuat dari daun tom.

Proses mewarna dengan soga pada umumnya dilakukan dengan cara meren-dam kain batik ke dalam larutan warna soga. $\mathrm{Na-}$ mun demikian tidak sedikit para pembatik mewarna soga hanya dengan mengoles-oleskan warna dengan menggunakan berus atau kuas. Khusus untuk wedel proses ini dilakukan dengan sangat hati-hati. Bahkan para pembatik jarang yang melakukan proses ini. Medel biasaya dilakukan khusus oleh tukang wedel. Caranya, para pembatik yang kainnya siap untuk diwedel dikumpulkan oleh orang tertentu kemudian dibawa ke tempat tukang wedel.

Medel dilakukan dengan cara: pertama membuat larutan nila, iaitu daun tom dipotong-potong dimasukkan ke dalam air dalam bak yang telah disediakan. Daun tersebut direndam selama lebih kurang 1 minggu. Setiap pagi dan petang diaduk/dikacau supaya cepat larut. Setelah larutan daun tom mendap ke bawah sisa-sisa daun tom dibersihkan, maka jadilah pewarna nila seperti jenang. Kedua siap-kan air dalam bak kemudian nila dicam-pur sedikit batu kapur/kapur sirih dan diaduk/dikacau sampai rata.

Setelah itu kain batik yang akan dimasukkan ke dalam larutan nila, dibasahi dengan air biasa ter-lebih dahulu baru dimasukkan ke dalam larutan nila. Agar warna nila meresap merata, maka kain tersebut dibolak-balik sampai benar-benar rata, setelah itu diren-dam beberapa saat baru diangkat dan dicuci dengan air bersih sampai sisa-sisa zat pewarna di atas permukaan kain ber-sih. Setelah dicuci kain dijemur ditempat yang teduh atau ditempat yang tidak lang-sung kena sinar matahari, supaya warna tidak cepat pudar/hilang.

\section{Bahan Pewarna Kimia}

Proses pewarnaan kimia secara umum sama dengan proses batik tradisional di daerah lainnya. Pewarna yang digunakan adalah Naptol Garam Naptol.

\section{USAHA-USAHA PELESTARIAN BATIK GEDHOG}

Batik sebagai aset budaya bangsa Indonesia perlu dilestarikan bahkan dikembangkan agar dapat mengikuti persaingan global. Bentuk-bentuk usaha tersebut dapat dilakukan berbagai macam cara diantaranya:

1. Mencintai dan mau berpakaian batik buatan dalam negara;

2. Mendukung usaha pemerintah untuk berpakaian batik di hari Jumat. Maka di Tuban juga bisa melaksanakan hal ini dengan menggunakan batik gedhog; 


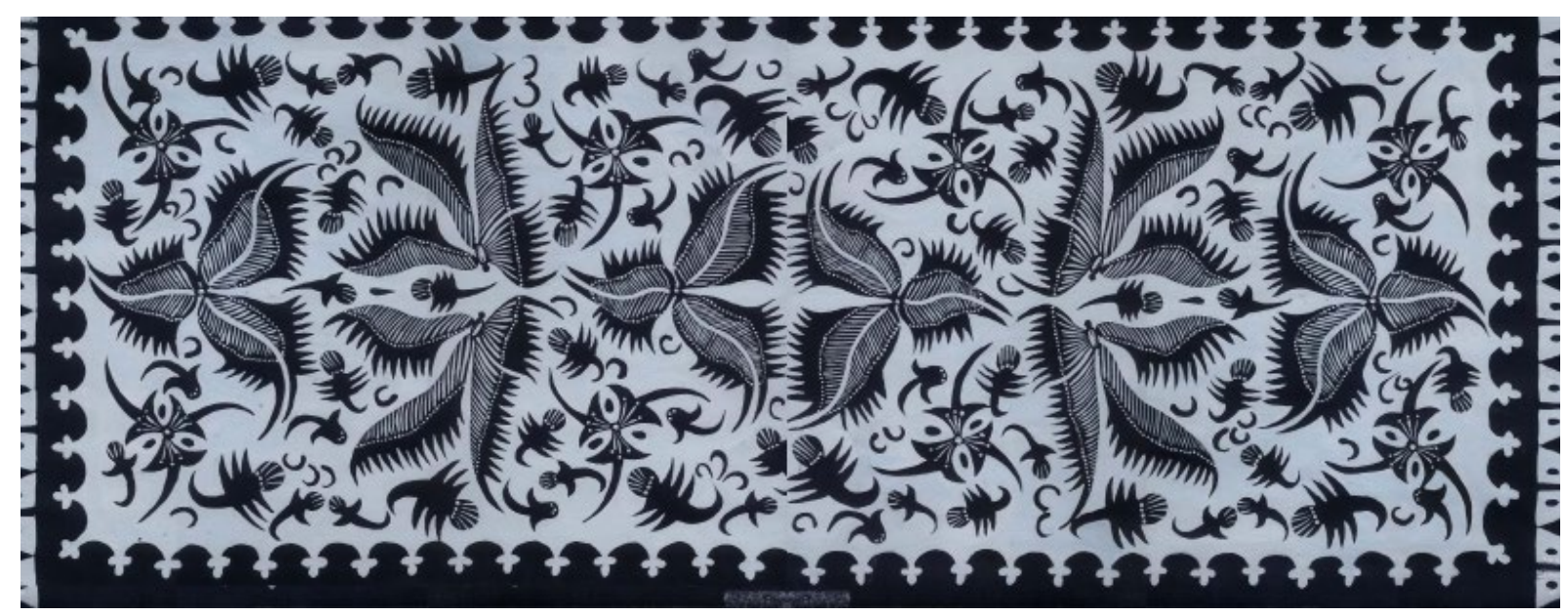

Gambar 1. Motif khas Batik Gedgog Tuban. Sumber : https://jawatimuran.files.wordpress. com/2011/08/batik_tuban-1.jpg, diunduh Maret, 2014.

3. Meningkatkan penggunaan bahan ba-tik. Pada tahun 2002 empat peneliti dari Badan RisetKelautan dan Perikanan (BRKP) yang bernama Yunizal, TAZwir, M NOOR DAN THAMrin WiKanATA, telah berusaha keras untuk mempertingkat-kan penggunaan bahan batik. Mereka telah menemukan rumput laut sebagai bahan pewarna batik. Menurut mereka pembuatan batik dapat dilaksanakan secara tepat, jika ditambahkan tiga persen natrium alginat yang diekstrak dari rumput laut coklat jenis Sargassum Fili-pendula dan Turbinaria (lihat internet,http://www. forek.or.id/detail. php?rubrik=iptek\&beritaID=458).

Dengan penemuan "rumput laut" se-bagai bahan pewarna batik, maka Men-teri Kelautan dan Perikanan Dr. Ir. Rokhmin Dahuri berupaya agar sepan-jang tahun 2002 ini harus berdiri lima pabrik baru pengolahan rumput laut. Kelima pabrik itu dua berada di Sulawesi Selatan serta masing-masing satu pabrik di Papua, Lampung dan Jawa Tengah (lihat http://www.forek.or.id/detail.php? Ru-brik =iptek\&beritaID $=458)$.

4. Membuat motif sesuai pasar global

Motif yang sudah ada perlu dikem-bangkan lagi khususnya mengenai permintaan desain batik yang sesuai dengan selera segmentasi pasar global. Adanya peran pasar global dalam industri batik telah menuntut tampilan visual dari batik itu sendiri agar lebih sesuai dengan selera masyarakat dunia saat ini. $\mathrm{Na}-$ mun hingga kini tampilan visual batik gedhog Tuban belum menjawab tantangan tersebut. Kebanyakan motifnya masih mengandalkan referensi motif dan corak lokal.

5. Promosi atau pameran

Dirjen Industri dan Dagang Kecil Menengah Departemen Perindustrian dan Perdagangan, MARwoto mengatakan, untuk meningkatkan pendapatan eksport dari sektor batik, perlu dilakukan promosi yang besar-besaran, seperti dalam bentuk pameran, sekaligus untuk memperkenalkan motif baru dari batik tersebut.

6. Meningkatkan kualitas kain sebagai ba-han dasar batik.

Jika diamati secara seksama, kain batik gedhog memiliki permukaan kain yang sangat kasar, hal ini dianggap perlu untuk peningkatan kualitas kain yang lebih baik.

7. Pembinaan dan perlindungan pemerintah setempat.

Pada saat ini Tuban sedang berkem-bang menjadi kota industri (baja dan semen). Kondisi ini membawa pengaruh negatif ter- 
hadap perkem-bangan batik tradisional di Tuban. Hasil wawancara dapat penulis simpulkan, yaitu dengan berkembangnya Tuban sebagai kota industri banyak pembatik yang berhenti membatik dan berku-rangnya lahan untuk menanam kapas.

Kondisi ini jika dibiarkan dapat meng-hambat perkembangan batik gedhog. Oleh karena itu batik gedhog diperlukan upaya pembinaan dan perlindungan dari pemerintah setempat.

\section{BRAND IMAGE DALAM PANGSA PASAR}

Dalam hal ini penulis telah melakukan survei di THR Surabaya dan Giant Sidoarjo. Penulis mengamati 2 buah toko Assesoris Harley ukuran $3 \mathrm{~m} \times 3 \mathrm{~m}$ dengan sewa 5 juta perbulan. Toko sekecil itu bisa meraup keuntungan besar dan mampu membayar sewa lima juta perbulan, apa strateginya. Berikut hasil wawancara dari kedua pemilik toko:

1. Membangun image yang kuat terhadap barang yang dijual, dengan memberikan pelayanan khusus bagi para pembeli.

2. Mengatur pangsa pasar. Barang yang dijual diperuntukkan bagi para kolektor. Jadi tidak semua orang menyukai barang ini. Karena barang yang dibuat menjadi antik, maka semahal apapun tetap akan dibeli orang.

3. Kemasan barang dibuat sebagus mung-kin untuk memberikan daya tarik pembeli.

Ketiga stretegi tersebut dapat dilakukan terhadap batik gedhog Tuban, agar tetap lestari.

\section{KESIMPULAN}

Batik Gedhog merupakan batik tradi-sional yang ada di Kecamatan Kerek Tuban. Semua proses pengerjaannya dil-akukan dengan tangan manual termasuk dalam membuat kainnya. Karena kainnya dibuat dengan tangan secara manual, maka permukaan kain menjadi kasar.

Hal ini mempengaruhi motif batik yang dihasilkan. Selama ini motif yang dihasilkan cenderung motif geometris mengikuti alur kain yang kasar. Melihat kondisi seperti ini, maka penulis kwatir batik gedhog akan habis ditelan zaman.

Terlebih di era globalisasi. Oleh karena itu perlu usaha untuk melestarikannya. Usaha ini diantaranya adalah memper-baiki kualitas kain, penyesuaian motif di-era sekarang, promosi, dan meningkatkan brand image.

\section{DAFTAR PUSTAKA}

Batik Gedhog Tuban.

1992/1993. Bagian Proyek Pembinaan Permuseuman Jawa Timur.

Ciptandi, Fajar.

2013 Pengaruh Pasar Global Terhadap Visualisasi Motif Batik Indonesia. Blog. Stisitelkom.ac.id.

Commodity Profile Batik Traditionan Tuban.

2000 Tuban: Departemen Perindustrian dan Perdagangan RI Kantor De-partemen Perindustrian dan Perdagangan Kabupaten Tuban.

DJUMENA, NiAn S.

1990 Batik and its Kind. Jakarta: Djambatan.

Dofa, Anesia Aryunda.

1996 Batik Indonesia. Jakarta: Penerbit PT Golden Terayon Press.

Kabupaten Tuban Dalam Angka.

2000 Tuban: Badan Pusat Statistik Kabupaten Tuban.

KARSAM.

2005 Seni Membatik Tulis Di Kota Bharu, Kelantan, Malaysia dan Di Kabu-paten Tuban, Jawa Timur, Indonesia: Satu Kajian Perbandingan. Desertasi. Kuala Lumpur: Universiti Malaya. 
Santosa, Purbaya Budi.

2004 Eksistensi Koperasi: Peluang dan Tantangan di Era Pasar Global. Dinamika Pembangunan. Vol.1 No. 2/Desember 2004: 111-117.

Wenas, Andre Vinsent.

2013 Konstelasi Pasar Global Terus Bergeser. Reposito-ry.usu.ac.id. 